\title{
Oxymoronic Legalism in the Ghanaian Supreme Court? Case Comment on Attorney-General V Faroe Atlantic Co Ltd.
}

\author{
Richard Obeng Mensah' \\ 1 Faculty of Law, Kwame Nkrumah University of Science and Technology, Kumasi - Ghana.
}

\begin{abstract}
In 2005, the Supreme Court of Ghana in Attorney-General v Faroe Atlantic Co Ltd rendered its decision on the interpretation of Article 181(5) of the 1992 Constitution. The Court's decision influenced its subsequent decisions in 2011 and 2012 on the scope and application of Article 181(5). This Case Comment reveals that the Court's interpretation in relation to the PPA in question was oxymoronic in that it simultaneously held the PPA as both valid and void. The author argues that the Court would have rendered a clearer and fairer decision if it had wholly interpreted Article 181. Its partial interpretation, needless bureaucratic judicial process, and the Government's lack of due diligence are disincentives to private investment in Ghana's power sector.
\end{abstract}

Keywords: Ghana, PPA, investment dispute, interpretation, illegal contract, power crisis, power sector investment.

(C) 2021 The Author(s). Published and Maintained by Noyam Publishers.

This is an open access article under the CCBY license (http://creativecommons.org/licenses/by/4.0/).

\section{INTRODUCTION}

On 26th January 2005, the Supreme Court of Ghana in the case of Attorney-General v Faroe Atlantic Co $L t d^{1}$ (hereafter called the Faroe Atlantic case) rendered its decision on the interpretation of Article 181(5) of the 1992 Constitution of the Republic of Ghana. The Court's decision influenced its subsequent decisions in $2011^{2}$ and $2012^{3}$ on the scope and application of Article 181(5). The Faroe Atlantic case is unique in several regards: it is the first case that turned on the interpretation of Article 181(5), the Court's preferred partial interpretation and oxymoronic application of Article 181(5), and the implication of the delays and decisions of the courts on private investment in Ghana's power sector and power crisis. This case comment provides an overview of the Faroe Atlantic case, its factual background, the Court's interpretation of Article 181(5) and an analysis of the said interpretation and its application in the case. This paper argues that the Supreme Court would have rendered a clearer and fairer decision if it had wholly interpreted Article 181.

\section{Factual Background}

On 24th July 1998, the Plaintiffs-Respondents (Plaintiffs) entered into a Power Purchase Agreement (PPA) with the Government of Ghana for the purchase of electric power. ${ }^{4}$ The Plaintiffs alleged a breach of the agreement and sued the Attorney-General, representing the Government of Ghana, in the High Court, Accra, claiming specific performance or in the alternative damages for breach of contract. The Plaintiffs on 8th

\footnotetext{
A-Gv Farole Atlantic Co Ltd, [2005-2006] SCGLR.

Ex parte Attorney-General, [2011] 2 SCGLR 1183.

A-G v Balkan Energy Ghana Ltd \& Others, [2012] 2 SCGLR 998.

4 A-G v Faroe Atlantic Co Ltd (2005-2006] SCGLR, 273.
} 
September 1998 applied for summary judgement and the trial High Court entered final judgement against the Defendant for the reliefs endorsed on the Writ of Summons. The Defendant did not appeal against the judgement.

The trial High Court on 18th September 2001, subsequent to a motion filed by the Plaintiffs on 8th September 1998 to enforce the summary judgment, gave judgment to the Plaintiffs in the sum of US\$6,298,354 as damages plus interest and an assessed damage of $\phi 100,000,000 .{ }^{5}$ The trial court also ordered the Plaintiffs to refund an advance payment of US $\$ 855,000$ paid by the Government of Ghana under the agreement. The Defendant appealed to the Court of Appeal but the appeal was dismissed. The Court of Appeal affirmed the trial court's decision to hear the evidence on damages and confirmed the award of damages. ${ }^{6}$

The Defendant on 23rd September 2003 appealed to the Supreme Court and questioned the legality of the summary judgement entered against it and the subsequent damages founded on the summary judgment. ${ }^{7}$ Counsel for the Defendant argued that the PPA, although validly concluded, was void for non-compliance with Article 181(5) of the 1992 Constitution. ${ }^{8}$ The Court unanimously allowed the appeal and held that the contract was unconstitutional and void for non-compliance with Article 181(5) of the 1992 Constitution. ${ }^{9}$

\section{Interpretation of Article 181(5) ${ }^{10}$}

Article 1(2) of the 1992 Constitution of the Republic of Ghana makes any law or act that is inconsistent with any provision of the Constitution void. This means that an act such as formation of a contract that does not conform to the provisions of the Constitution is void. A void contract has no legal effect from the onset. ${ }^{11}$ Consequently, a void contract is legally unenforceable because it is deemed to have never existed. ${ }^{12}$

Counsel for the Defendant in the Faroe Atlantic case had argued that because the PPA constituted a loan agreement in light of the 1992 Constitution of Ghana, hence 'failure to lay it before Parliament for approval, constituted a gross violation of Article 181(5) of the Constitution, rendering it ineffectual, and a complete nullity, utterly incapable of creating any rights, benefits or liabilities'. ${ }^{13}$ For Georgina Wood JSC, as she then was, the crux of the foregoing argument is that the Plaintiffs were not entitled to any damages because the 'PPA is clearly an unenforceable contract'. ${ }^{14}$

The Supreme Court of Ghana examined the constitutionality of the PPA in the Faroe Atlantic case in the light of Article 181 of the 1992 Constitution of Ghana, which reads as follows:

181. (1) Parliament may, by a resolution supported by the votes of a majority of all the members of Parliament, authorise the Government to enter into an agreement for the granting of a loan out of any public fund or public account. ${ }^{15}$

(2) An agreement entered into under clause (1) of this Article shall be laid before Parliament and shall not come into operation unless it is approved by a resolution of Parliament. ${ }^{16}$

(3) No loan shall be raised by the Government on behalf of itself or any other public institution or authority otherwise than by or under the authority of an Act of Parliament.

(4) An Act of Parliament enacted in accordance with clause (3) of this Article shall provide -

(a) that the terms and conditions of a loan shall be laid before Parliament and

\footnotetext{
5 A-G v Farole Atlantic Co Ltd, [2005-2006] SCGLR, 274.

A-G v Farole Atlantic Co Ltd, [2005-2006] SCGLR.

A-G v Farole Atlantic Co Ltd, 275.

A-G v Farole Atlantic Co Ltd, [2005-2006] SCGLR.

9 A-G v Farole Atlantic Co Ltd, [2005-2006] SCGLR, 278.

101992 Constitution.

11 John B Saunders (eds), Words and Phrases Legally Defined, vol Volume 1 A-C (Butterworth \& Co (Publishers) Ltd 1969$), 336$.

12 Garner and Black, Black's Law Dictionary.

13 A-G v Faroe Atlantic Co Ltd, 307.

14 A-G v Farole Atlantic Co Ltd, [2005-2006] SCGLR 296.

15 Emphasis is mine.

16 Emphasis is mine.
} 
shall not come into operation unless they have been approved by a resolution of Parliament; and

(b) that any moneys received in respect of that loan shall be paid into the Consolidated Fund and form part of that Fund or into some other public fund of Ghana either existing or created for the purposes of the loan.

(5) This Article shall, with the necessary modifications by Parliament, apply to an international business or economic transaction to which the Government is a party as it applies to a loan.

Article 181 of the 1992 Constitution seeks to 'ensure transparency, openness and parliamentary consent in relation to (loan agreements and international business or economic transactions) ${ }^{17}$ which the Government of Ghana is a party. The ordinary meaning of Article 181(5) enjoins the Government to "comply with the requirements, mutatis mutandis, imposed by Article 181 of the Constitution' ${ }^{18}$ when it enters into an international business or economic transaction such as the PPA in the instant case. ${ }^{19}$ According to the Court, the requirements 'include the laying of the relevant agreement before Parliament in terms of clause (1) and under clause (2), (and) the agreement is not to come into operation unless it is approved by a resolution of Parliament' ${ }^{20}$ The Court reasoned that the PPA was unconstitutional and void because it did not conform to Article 181(2) of the Constitution. ${ }^{21}$

However, a closer reading of Article 181 as a whole will reveal that the Court's conclusion on the unconstitutionality of the PPA is partial and problematic. The question is: was the PPA unconstitutional and void only because it did not receive parliamentary approval in terms of Article 181(2)? The author does not think so. Article 181(2) takes its colour and force from Article 181(1). It clearly refers to an agreement entered into under clause (1) of Article 181. It could thus be inferred from Article 181(1) that the Government of Ghana cannot enter into an agreement for the grant of a loan out of any public fund or public account without prior authorisation by Parliament. It is argued that Article 181(1)-(2) obliges the Government to seek prior parliamentary authorisation to enter into a relevant agreement, and that the government must subsequently seek parliamentary approval before the agreement can come into force. This means that a relevant agreement that complies with Article 181(2) is void if the Government did not obtain prior parliamentary authorisation 'to enter' into that agreement unless this requirement is dispensed with by Parliament. Sophia Akuffo JSC noted in her judgement that any transaction to which Article 181 is applicable that is 'concluded without the authorisation of Parliament cannot take effect without such authorisation'. ${ }^{22}$ However, both the counsel of the Defendant and the Court failed to point out the legal effect of non-compliance with the prior authorisation requirement under Article 181(1).

It is therefore submitted that the PPA was void in terms of both clauses (1) and (2) of Article 181. This is because according to the facts of the instant case, the Government did not comply with the foregoing clauses. ${ }^{23}$ This paper suggests that compliance with both clauses ensures greater transparency and openness, which Article 181 seeks to achieve, ${ }^{24}$ since it gives Parliament ample time to get informed about and scrutinise the relevant agreement before approving it. The Supreme Court, in the instant case, placed too much emphasis on Article 181(2) and by so doing failed to adequately discuss the requirement under clause (1). Although Dr. Date-Bah JSC in his analysis of Article 181(5) pointed out the requirement under clause (1), ${ }^{25}$ his conclusion only suggests that the PPA was unconstitutional and void because it was not submitted for parliamentary

\footnotetext{
17 A-G v Faroe Atlantic Co Ltd, 296.

18 A-G v Faroe Atlantic Co Ltd

19 A-Gv Farole Atlantic Co Ltd, [2005-2006] SCGLR.

20 A-G v Farole Atlantic Co Ltd, 294.

21 A-G v Farole Atlantic Co Ltd, 294-295.

22 A-G v Farole Atlantic Co Ltd, 278.

${ }^{23}$ A-G v Farole Atlantic Co Ltd, 294-295, 301-303.

${ }^{24}$ A-G v Farole Atlantic Co Ltd, 295-296.

${ }_{25}$ A-G v Farole Atlantic Co Ltd, 294.
} 
approval ${ }^{26}$ in terms of clause (2). However, this conclusion, with all due respect, is an erroneous appreciation of the true intendment of the entire Article 181.

It may be argued that Article 181(1) is discretionary while Article 181(2) is mandatory. This argument may suggest that Article 181(1), being discretionary, does not impact the validity of Article 181(2). This may be because if that was the case Article 181(1) would have expressly indicated that where no prior authorisation is sought, then a relevant agreement is void but the framers of the Constitution attached the issue of 'validity' only to Article 181(2). This argument may, however, be overstretching because the discretion under Article 181(1) only lies with Parliament, not the Executive. Besides, Article 181(2), as discussed earlier, takes its colour and force from Article 181(1) except perhaps in cases where Parliament exercises its discretion to dispense with the requirement under Article 181(1). This means that prior authorisation is a necessary condition. If prior authorisation under Article 181 was not a necessary condition, clause (1) would have been silent on it. For instance, Article 75(1) of the 1992 Constitution empowers the President of Ghana to execute or cause to be executed agreements in the name of Ghana. Clause (2) of Article 75, however, subjects the agreement in question to ratification by an Act of Parliament or a resolution by more than $50 \%$ of members of Parliament. The President in this instance needs no prior authorisation from Parliament to enter into the relevant agreement. Nevertheless, the agreement in question can only be validated and made enforceable when Parliament ratifies it. In the absence of any such ratification, the agreement in question will be deemed void in the light of Article 1(2) of the 1992 Constitution. It may thus be concluded that while Article 75(1) does not require prior parliamentary authorisation, Article 181(1) expressly makes it a necessary requirement unless parliament dispenses with it.

\section{Interpreting the PPA as Unconstitutional and Void but Valid for Restitution}

Dr. Date-Bah JSC in his judgment stated a trite legal principle, namely 'Money paid under an illegal contract cannot be recovered'. ${ }^{27}$ The Supreme Court in the Faroe Atlantic case concluded that the PPA was valid yet void for constitutionality ${ }^{28}$ because it was not laid before Parliament for approval. For Dr. Date-Bah JSC, the PPA was not 'an illegal contract in the common law sense. ${ }^{29}$ Rather, it is a contract that is null and void and unenforceable for constitutional reasons. Restitution of money paid under such a contract should be allowed' ${ }^{30}$ Consequently, the Court ordered the refund of the US\$855,000 being the advance money the Government of Ghana paid to the Plaintiffs. ${ }^{31}$

It is humbly submitted that the PPA in the instant case cannot be unconstitutional and void on one hand, and valid and enforceable on the other hand. It beats legal imagination and analysis that an agreement be declared void, and for that matter non-existent, for one reason and be simultaneously declared valid for a particular purpose among others; the refund of money paid under it. As earlier argued, non-compliance with Articles 1(2) and 181(1)-(2) of the 1992 Constitution rendered the PPA void for the lack of prior authorisation and subsequent approval by Parliament in relation to the PPA. Consequently, the Government's lack of authorisation or capacity affected the validity of the PPA ${ }^{32}$ and made it absolutely void.

It is thus surprising for the Court to conclude that the PPA, which was not brought to the notice of Parliament in terms of clauses (1) and (2) of Article 181, was a valid contract. The Court, however, failed to point out the basis for holding that the PPA was a valid contract. It may be suggested that the PPA is valid because it complied with the requirements of a valid contract such as Agreement, Capacity to contract, Consideration and Intention to create legal relation. It is submitted that this reasoning is sound in the case of Agreements under Article 75 but not those under Article 181. This is because while Article 75 gives the President an express authority to enter into treaties and agreements, Article 181(1) gives no such express authorisation if the Agreement in question relates to a loan or an international business or economic transaction. In the light

\footnotetext{
6 A-Gv Farole Atlantic Co Ltd, 297, 302.

A-G v Farole Atlantic Co Ltd, [2005-2006] SCGLR, 302.

28 A-G v Farole Atlantic Co Ltd, 278-279, 302, 310-311..

${ }^{29}$ Emphasis is mine.

${ }^{30}$ A-G v Farole Atlantic Co Ltd, [2005-2006] SCGLR, 279, 302.

31 A-Gv Farole Atlantic Co Ltd.

32 Joseph Chitty and Hugh Beale, Chitty on Contracts. Thirty-Second edition. The Common Law Library (London: Sweet \& Maxwell : Thomson Reuters), 2015, 837.
} 
of Articles 1(2) and 181(1)-(2), the PPA was an unauthorised agreement and for that matter illegal and void.

This paper also differs with the legal opinion of Dr. Date-Bah JSC that the PPA was not 'an illegal contract in the common law sense'. This conclusion by Dr. Date-Bah JSC seems to imply that there is an understanding of illegality of contract in Common Law that does not apply to the Faroe Atlantic case. At Common Law, there is an 'unwillingness to condemn otherwise valid contracts as unworthy of legal recognition on the grounds of illegality or public policy'. ${ }^{33}$ In general, a contract may be 'illegal' at Common Law if it is prohibited by law, contrary to public policy, or tainted with crime, fraud or breach of trust. ${ }^{34}$ Huntley has observed that, "[s]ome categories of contracts or contractual terms (such as covenants in restraint of trade) may simply be unenforceable because they offend policy...although they are not illegal in the strict sense of the word'. ${ }^{35}$ It is submitted that though Dr. Date-Bah's conclusion is correct in the light of Huntley's observation, the conclusion of the learned judge is wrong in the sense that the formation of the PPA in question breached the legal requirements under Article 181 of the 1992 Constitution of Ghana.

A contract may be illegal in two main senses - narrow and wider. In the narrow sense, a contract is illegal if it is contrary to public policy because it involves the commission of a legal wrong. ${ }^{36}$ In the wider sense, a contract is illegal and thus unenforceable because of public policy ${ }^{37}$ although it does not involve an unlawful act. ${ }^{38}$ Thus, public policy may invalidate a contract if the contract's object is made illegal by legislation, or if its object is economically against public interest. ${ }^{39} \mathrm{~A}$ contract may also be illegal if it is entered into without complying with a legal requirement. ${ }^{40}$ It is suggested that the formation of the PPA, in this case, was against both public interest and public policy of Ghana because it flouted Article 181(1)-(2) and (5) of the 1992 Constitution. A business or economic transaction under Article 181(5) 'impacts on the wealth and resources of (Ghana) ${ }^{\prime 41}$ hence non-compliance with clauses (1) and (2) is offensive to the public interest and public policy because such a conduct is inconsistent with the 1992 Constitution of Ghana. The PPA was therefore void under Article 1(2) of the Constitution for non-compliance with the legal requirements under Article 181(1)-(2). This means that the PPA, being void, was "never made."42 Even though a contract that is illegal as to formation is "unenforceable" rather than "void," ${ }^{43}$ Articles 1(2) and 181(1)-(2) of the 1992 Constitution of Ghana make the PPA in the instant case both void and unenforceable. ${ }^{44}$

A restitutionary relief may be available under an illegal contract 'but such a relief will be refused where "allowing the cause of action to be maintained [would] make nonsense of the refusal to enforce the contract." 45 The purpose of this legal proposition is to enhance legal coherence because allowing such restitutionary remedy may defeat the policy rendering the contract illegal. ${ }^{46}$ This paper submits that the restitutionary relief endorsed by the Supreme Court of Ghana, in this case, will enhance legal certainty and coherence since Articles 1(2) and 181(1) of the 1992 Constitution of Ghana make the PPA both void and unenforceable, not just unenforceable. This submission resonates with the reasoning of Dr Date-Bah JSC on Article 1(2) as follows:

Thus, if even statute law is void if in conflict with the Constitution, a fortiori, contracts breaching the Constitution should not be enforced...This court needs not overturn the summary judgment... But it can take account of the constitutional requirement that a contract such as that sued on in this case shall not come into operation unless approved by Parliament, when determining the outcome of the case before it. The constitutional provision in terms of Article 1(2), in my view,

\footnotetext{
33 John A K Huntley (ed), Contract: Cases and Materials (Green / Sweet \& Maxwell 1995) 232.

34 Huntley, Contract, 232.

35 Huntley, Contract, 232

${ }^{36}$ Chitty and Beale, Chitty on Contracts, 837.

37 Emphasis is mine.

38 Chitty and Beale, Chitty on Contracts, 837.

39 Chitty and Beale, Chitty on Contracts, 1239.

40 Chitty and Beale, Chitty on Contracts, 1248-1249.

${ }^{41}$ A-G v Balkan Energy Ghana Ltd \& Others, 1035.

${ }^{42}$ Chitty and Beale, Chitty on Contracts, 1248-1249.

${ }^{43}$ Chitty and Beale, Chitty on Contracts, 1248-1249.

44 A-Gv Faroe Atlantic Co Ltd, 298.

${ }^{45}$ Chitty and Beale, Chitty on Contracts, 1361.

${ }^{46}$ Chitty and Beale., Chitty on Contracts, 1361.
} 
is a peremptory norm that has to be heeded by this court. ${ }^{47}$

Generally, money paid under a void contract may warrant restitution to prevent unjust enrichment of a party. ${ }^{48}$ A void contract as a matter of law is no contract hence nothing needs to be set aside before a restitution claim can be brought. ${ }^{49}$ It has been argued that a claimant who has transferred a benefit to a defendant pursuant to a contract which is void cannot receive the expected consideration from the other party as a matter of law. ${ }^{50}$ This is because the contract being void and non-existent vitiates the claimant's intention that the defendant should receive the benefit (consideration). Thus 'the benefit which the claimant expected to receive under the contract was never owed since no obligations to benefit the claimant existed as a matter of law'. ${ }^{51}$ This argument may mean that a defendant can never provide consideration as a matter of law in a void contract even though the claimant had actually received a consideration. ${ }^{52}$ It has been observed that payments made under a void contract have 'never (been) validly received....as a matter of law and could be ignored: the consideration had not just failed but was absent' ${ }^{53}$ However, the foregoing argument is very controversial and its validity is dependent on a particular context. ${ }^{54}$ For instance, restitution may be allowed on the ground of total failure of consideration in relation to a contract that is void for want of authority. ${ }^{55}$ Similarly, the Supreme Court in the instant case may be justified for ordering the Plaintiffs to refund the US\$855,000 to the Government of Ghana in line with the submission of this paper that the Government lacked authority under Article 181(1) to enter into the PPA. Thus the US\$855,000 being the consideration for the PAA had failed due to the lack of authority.

\section{VOID CONTRACTS AND RESTITUTION}

Swan has observed that contracts that are unenforceable, null or void usually present great difficulties to the Courts in certain cases. ${ }^{56}$ The case of Communities Economic Development Fund v Canadian Pickles Corporation (The Canadian Pickle case) ${ }^{57}$ is one of such cases. In the Canadian Pickles case, the Plaintiff institution (Appellant) exceeded its statutory powers ${ }^{58}$ in approving a loan to the Canadian Pickles, the Respondent company. ${ }^{59}$ The Directors of the company, including the individual Respondent, guaranteed the loan. The respondent company defaulted on the loan. ${ }^{60}$ The Appellant thus sued the Respondent and the guarantors for repayment. The Court of Queen's Bench held that the loan was ultra vires ${ }^{61}$ the Appellant '... because of the Appellant's failure to follow the procedures set out in (a legislation)'. ${ }^{62}$ The Court nonetheless held that the individual Respondent was still obliged to honour his guarantee because he encouraged the Appellant to lend the money and has benefited from it as a shareholder. The Court of Appeal, on appeal, reversed the judgment and dismissed the action. ${ }^{63}$ Husband JA concluded as follows:

...[T] hat an ultra vires loan is not an illegal contract, it is a nullity. A guarantor cannot be liable for guaranteeing a loan which is void from the outset. The loan being a nullity, the guarantee is a "meaningless document upon which no legal action can be founded". ${ }^{64}$

\footnotetext{
47 A-Gv Faroe Atlantic Co Ltd, 298.

48 Graham, Virgo. The Principles of the Law of Restitution. 2nd ed. Oxford ; New York: Oxford University Press, $2006,371$.

49 Virgo, The Principles of the Law of Restitution, 371.

50 Virgo, The Principles of the Law of Restitution, 371.

51 Virgo, The Principles of the Law of Restitution, 371.

52 Virgo, The Principles of the Law of Restitution, 371.

53 Virgo, The Principles of the Law of Restitution, 449.

54 Virgo, The Principles of the Law of Restitution, 371-372.

55 Virgo, The Principles of the Law of Restitution, 373.

56 John Swan, "The "Void" Contract; Ultra Vires and Illegality: The Communities Economic Development Fund v Canadian Pickles Corporation and Maxwell (Commentary)’, 1992-1993, 115, 116.

57 Communities Economic Development Fund v Canadian Pickles Corporation (1991) 3 (SCR) 388.

58 Communities Economic Developement Fund v Canadian Pickles Corporation, 397.

59 Communities Economic Developement Fund v Canadian Pickles Corporation, 388-389.

${ }^{60}$ Communities Economic Developement Fund v Canadian Pickles Corporation, 388-389.

${ }^{61}$ Exceeding one's statutory power.

${ }^{62}$ Communities Economic Developement Fund v Canadian Pickles Corporation, 398.

${ }^{63}$ Communities Economic Developement Fund v Canadian Pickles Corporation, 388-389.

${ }^{64}$ Communities Economic Developement Fund v Canadian Pickles Corporation, 398.
} 
The Appellant unsuccessfully appealed to the Canadian Supreme Court. The Court reasoned, 'The Respondent is not liable to repay the ultra vires loan as guarantor ${ }^{\prime 65}$ because the principal debt was ultra vires,${ }^{66}$ and that the Respondent did not receive money from the appellant. ${ }^{67}$ Thus the individual Respondent would have been liable if he had received the money based on "equity in action" 68 and the principle of conscionability. ${ }^{69}$ The foregoing judgments thus distinguish contracts that are illegal and those that are ultra vires the power of a contracting party and suggest that the loan agreement in the instant case was a nullity, but was not illegal. ${ }^{70}$ This case has however been criticised for failing to address critical questions such as whether a borrower could be sued on an ultra vires loan. ${ }^{71}$

The Canadian Pickles case is factually distinguishable from the Faroe Atlantic case. However, one thing that is common to both cases is the conclusion of the Courts that a contract which is a nullity is not necessarily an illegality hence restitution could be allowed in such cases. This conclusion is, however, problematic in cases where a contract is both a nullity and an illegality in relation to a relevant legislation or public policy. ${ }^{72}$ Restitution may be allowed under void and illegal contracts if it will further public policy, the purpose of a legislation ${ }^{73}$ or prevent an unjust enrichment. ${ }^{74}$ As earlier argued, the Government of Ghana lacked the needed authorisations under Article 181(1)-(2) of the 1992 Constitution to enter into the PPA hence the order for refund of the advance payment it made to the Plaintiffs.

However, after ordering the refund, the Court should have also ordered the payment of any expenditure made by the Plaintiffs so far in order to put both parties, as much as possible, in their original positions before the PPA was concluded. It is inequitable to hold damages awarded in favour of the Plaintiffs unenforceable yet order refund to the Defendant money paid in advance to the Plaintiffs when it was the Defendant who occasioned the breach that resulted in the unenforceability of the PPA. The unmeritorious Defendant in the Faroe Atlantic case thus ought not to have been allowed to be enriched unjustly. ${ }^{75}$

\section{Implication of the Decision in Faroe Atlantic Case on Private Investment in Ghana's Power Sector and Power Crisis}

This paper argues that the oxymoronic decisions in the Faroe Atlantic case and the bureaucratic judicial proceedings that characterised it are disincentives to potential investors to Ghana's power sector.

Ghana has had five major power crises since $1984^{76}$ despite several reforms in its power sector. ${ }^{77}$ Ghana is among the top 10 countries in the world that have experienced and continue to experience crippling load shedding. ${ }^{78}$ One of the root causes of this trend in Ghana is the failure to invest in the power sector ${ }^{79}$ more particularly investment in electricity infrastructure. ${ }^{80}$ Ghana's inadequate power supply infrastructure is

${ }_{65}$ Communities Economic Developement Fund v Canadian Pickles Corporation, 398.

${ }^{66}$ Communities Economic Developement Fund v Canadian Pickles Corporation, 390.

${ }^{67}$ Communities Economic Developement Fund v Canadian Pickles Corporation, 417.

${ }^{68}$ Communities Economic Developement Fund v Canadian Pickles Corporation, 398.

69 Communities Economic Developement Fund v Canadian Pickles Corporation, 399.

70 Swan, The "Void" Contract, 117.

71 Swan, The "Void" Contract, 121.

72 Chitty and Beale, Chitty on Contracts, 387.

73 Chitty and Beale, Chitty on Contracts, 118-123.

74 Graham Virgo, 'Case and Comment: Restitution of Void Loans,' Cambridge Law Journal 69, part 3 (2010) 371.

75 N.H Andrew, 'Case and Comment: Restitution and Void Contracts: The Unmeritorious Defendant Must Pay,' Cambridge LJ 49, no. 1 (1990) 15-17.

76 Paul Adjei Kwakwa, 'Energy-Growth Nexus and Energy Demand in Ghana: A Review of Empirical Studies,' Applied Research Journal 1, no. 1 (2014) 28-38.

77 Ishmael Edjekumhene, Martin Bawa Amadu, Abeeku Brew-Hammond, 'Power Sector Reform in Ghana: The Untold Story,' KITE (2001), accessed 15 September 2021, http://pdf.wri.org/power_politics/ghana.pdf

${ }^{78}$ Louis Schoeman, 'Top 10 Countries That Have Experienced and Continue to Experienced Crippling Load Shedding'. Power Plant, 15 May 2015. www.powerplanet.co.za/blog/top-10-countries-that-have-experienced-and-continue-to-experience-crippling-load-shedding.

79 Joseph Kapika, and Anton Eberhard. Power-Sector Reform and Regulation in Africa: Lessons from Kenya, Tanzania, Uganda, Zambia, Namibia and Ghana. Cape Town: HSRC Press, 2013.

${ }^{80}$ International Monetary Fund, 'Regional Economic Outlook: Sub-Saharan Africa'. World Bank, 2008. https://www.imf.org/external/pubs/ft/reo/2008/AFR/eng/sreo0408.pdf. 
also due to failure to sustain power sector investment programmes. ${ }^{81}$

Sub-Saharan Africa's energy use has risen by $45 \%$ since 2000 due to rapid economic growth. ${ }^{82}$ Many of its governments have thus intensified their efforts to tackle the numerous regulatory and political barriers that hold back investment in domestic energy supply. ${ }^{83}$ An estimated US $\$ 40.8$ billion a year in investments is needed for Africa's power sector and the private sector is expected to play a significant role in closing the demand-resources gap by providing funds and expertise. ${ }^{84}$ Ghana's total capital investment is estimated at US \$4.3-5.4 billion for the period 2006-2020 with investment in its electricity subsector taking over 70\% of the total amount. ${ }^{85}$ However, regulatory impediments and risks, among other factors, impede private investment in energy infrastructure in most developing African countries such as Ghana. ${ }^{86}$

The Faroe Atlantic case took seven years to decide; from the filing of the Writ in the High Court to the determination of the appeal by the Supreme Court. The case unnecessarily suffered series of adjournments at the High Court. ${ }^{87}$ It is submitted that this needless delay, coupled with the oxymoronic decisions of the Supreme Court, does not enhance investor confidence in Ghana's power sector.

Again, the Government of Ghana's lack of diligence, culminating in its failure to comply with the requirements of Article 181(1)-(2) of the 1992 Constitution of Ghana, wrongfully postulates that a private investor in Ghana's power sector risks losing its investment if the Government fails to exhaust all processes necessary to constitutionally validate an agreement under Article 181(5) of the 1992 Constitution of Ghana.

\section{CONCLUSION}

The Faroe Atlantic case is the first case on Article 181(5) of the 1992 Constitution of the Republic of Ghana. The decision of the Supreme Court has influenced subsequent cases brought under Article 181(5) such as the Balkan Energy Ghana case. ${ }^{88}$ This paper has argued that the Court would have rendered a clearer and fairer decision if it had wholly interpreted Article 181. The Court's partial interpretation and oxymoronic application of Article 181(5), the needless bureaucratic judicial process and delays that characterized the case, and the lack of due diligence on the part of the Government of Ghana are disincentives to private investment in Ghana's power sector. The lack of diligence on the part of the government should also put investors on notice to demand Parliamentary approval before making huge investments. Legal Counsel for such investors should also place an arbitration clause in PPAs, which will make it possible for the parties to have recourse to arbitration irrespective of whether or not the PPA is valid.

\section{ABOUT THE AUTHOR}

Richard Obeng Mensah is an assistant lecturer at the Private Law Department, Kwame Nkrumah University of Science and Technology, Kumasi - Ghana; where he teaches Intellectual Property Law, Comparative Law, and Ghana Legal System \& Method. His research interests include energy security, climate change, human rights, intellectual property rights, comparative law, and corruption and good governance. He has published in these areas among others. His ongoing doctoral research, at the Faculty of Law, KNUST, focuses on the role of the law in the use of clean development mechanism to promote sustainable investment in clean energy in Ghana. Richard holds a Bachelor of Laws (LLB) degree from KNUST, Qualifying Certificate in Law (QCL/ BL) from the Ghana School of Law, and a Master of Laws (LLM) degree in Energy Law from the University

\footnotetext{
${ }^{81}$ Ministry of Energy (Ghana), 'Energy Sector Strategy and Development Plan 2010'. February 2010. http://ghanaoilwatch.org/images/laws/energy_strategy.pdf.

82 International Energy Agency (IEA), 'Africa Energy Outlook: A Focus on Energy Prospects in Sub-Saharan Africa'.OECD/IEA accessed 15 February 2021.

https://www.iea.org/publications/freepublications/publication/WEO2014_AfricaEnergyOutlook.pdf

83 IEA 'Africa Energy Outlook: A Focus on Energy Prospects in Sub-Saharan Africa'

${ }^{84}$ Dambudzo Muzenda, 'Increasing Private Investment in African Energy Infrastructure' https:/www.oecd.org/investment/investmentfordevelopment/43966848.pdf. (accessed 4 June 2021).

85 'Strategic National Energy Plan 2006-2020'.

${ }^{86}$ Dambudzo Muzenda, 'Increasing Private Investment in African Energy Infrastructure'.

${ }^{87}$ A-G v Faroe Atlantic Co Ltd, 283.

${ }^{88}$ Ex parte Attorney-General, [2011] 2 SCGLR.
} 
of Aberdeen, Scotland, United Kingdom. He is a private legal practitioner and a member of the Ghana Bar Association and Advocates Africa/International.

\section{BIBLIOGRAPHY}

1992 Constitution (Ghana) (1992).

Andrew, N.H. 'Case and Comment: Restitution and Void Contracts: The Unmeritorious Defendant Must Pay'. Cambridge LJ 49, no. 1 (n.d.): 15

Attorney-General v Balkan Energy Ghana Ltd \& Others, No. No J6/1/2012 (Supreme Court 16 May 2012). Attorney-General v Faroe Atlantic Co Ltd, No. Appeal No J4/22/2004 (Supreme Court 26 January 2005). Chitty, Joseph, and Beale H.G., eds. Chitty on Contracts. Thirty-Second edition. The Common Law Library. London: Sweet \& Maxwell : Thomson Reuters, 2015.

Communities Economic Developement Fund v Canadian Pickles Corporation (SCR 1991).

Dambudzo Muzenda. 'Increasing Private Investment in African Energy Infrastructure'.NEPAD-

OECD Africa Investment Initiative, 11 November 2011, accessed 15 February 2021.

http://www.oecd.org/investment/investmentfordevelopment/43966848.pdf.

Edjekumhene, Ishmael, and Bawa Amadu Martin, Brew-Hammond Abeeku, 'Power Sector Reform in

Ghana: The Untold Story'. Kumasi Institute of Technology and Environment (KITE), January 2001. http://www.wri.org/sites/default/files/powerpolitics_ghana.pdf.

Garner, Bryan A. and Henry Campbell Black, eds. Black's Law Dictionary. 8th ed. St. Paul, MN: Thomson/ West, 2004.

Huntley, John A. K., ed. Contract: Cases and Materials. Edinburgh: Green / Sweet \& Maxwell, 1995.

International Monetary Fund. 'Regional Economic Outlook: Sub-Saharan Africa'. World Bank, 2008. https://www.imf.org/external/pubs/ft/reo/2008/AFR/eng/sreo0408.pdf.

International Energy Agency (IEA). 'Africa Energy Outlook: A Focus on Energy Prospects in Sub-Saharan Africa'. OECD/IEA, 2014.

https://www.iea.org/publications/freepublications/publication/WEO2014_AfricaEnergyOutlook.pdf. Kapika, Joseph, and Eberhard, Anton. Power-Sector Reform and Regulation in Africa: Lessons from Kenya, Tanzania, Uganda, Zambia, Namibia and Ghana. Cape Town: HSRC Press, 2013.

Kwakwa, Paul Adjei. 'Energy-Growth Nexus and Energy Demand in Ghana: A Review of Empirical Studies'. Applied Research Journal 1 (2014): 28-38.

Ministry of Energy (Ghana). 'Energy Sector Strategy and Development Plan 2010', February 2010. http://ghanaoilwatch.org/images/laws/energy_strategy.pdf.

Republic v High Court (Commercial Division), Accra; Ex Parte Attorney-General (Balkan Energy Ghana Ltd \& Others Interested Parties), No. Civil Motion J5/34/2011 (Supreme Court 2 November 2011).

Saunders, John B. Words and Phrases Legally Defined. Vol. Volume 1 A-C. Butterworth \& Co. (Publishers) Ltd, 1969.

Schoeman, Louis. 'Top 10 Countries That Have Experienced and Continue to Experienced Crippling Load Shedding'. Power Plant, 15 May 2015. www.powerplanet.co.za/blog/top-10-countries-that-haveexperienced-and-continue-to-experience-crippling-load-shedding.

'Strategic National Energy Plan 2006-2020'. Main Report. Energy Commission (Ghana), July 2006.

Swan, John. 'The "Void" Contract; Ultra Vires and Illegality: The Communities Economic Development Fund v Canadian Pickles Corporation and Maxwell (Commentary)'. Can Bus LJ 21 (1993, 1992).

Virgo Graham. 'Case and Comment: Restitution of Void Loans'. Cambridge LJ 69 (2010).

Virgo, Graham. The Principles of the Law of Restitution. 2nd ed. Oxford, New York: Oxford University Press, 2006. 